\title{
PENGARUH DAR, DER DAN TATA KELOLA PERUSAHAAN TERHADAP KINERJA KEUANGAN PERUSAHAAN FARMASI
}

\author{
Riesta Chahya Agustina ${ }^{1)}$, Awan Santosa ${ }^{2)}$. \\ ${ }^{1}$ Fakultas Ekonomi, Universitas Mercu Buana Yogyakarta \\ email: riesta508@gmail.com \\ ${ }^{2}$ Fakultas Ekonomi, Universitas Mercu Buana Yogyakarta \\ email: awan@mercubuana-yogya.ac.id
}

\begin{abstract}
This study aims to determine the effect of debt to asset ratio, debt to equity ratio and corporate governance on financial performance in pharmaceutical sub-manufacturing manufacturing companies listed on the Indonesia Stock Exchange for the period 2013-2017. The type of research used is quantitative research. The population in this study were all Pharmaceutical Manufacturing Sub-Sector Companies listed on the Indonesia Stock Exchange totaling 10 companies, while the sample for this study amounted to 8 Pharmaceutical Companies. The data collection technique in this study is to use documentation and literature study techniques. The results show, 1) debt to asset ratio does not significantly influence financial performance, 2) debt to equity ratio has a significant effect on financial performance, 3) corporate governance has a significant effect on financial performance, 4) debt to asset ratio, debt to equity ratio and corporate governance simultaneously have a significant effect on financial performance. the coefficient of determination (R2) obtained is 0.637 , meaning that the ability of the independent variable to describe the dependent variable is $63.7 \%$, while the rest $(100 \%-63.7 \%=$ $36.3 \%$ ). $36.3 \%$ are described by other factors outside the variables in the regression equation.
\end{abstract}

Keywords: Leverage Ratio, Debt to Asset Ratio, Debt to Equity Ratio, Corporate Governance, Financial Performance

Abstrak
Penelitian ini bertujuan untuk mengetahui pengaruh debt to aset ratio, debt to equity ratio dan tata kelola perusahaan terhadap kinerja keuangan pada perusahaan manufaktur sub sektor farmasi yang terdaftar di Bursa Efek Indonesia periode 2013-2017. Jenis penelitian yang digunakan adalah penelitian kuantitatif. Populasi dalam penelitian ini adalah Seluruh Perusahaan Manufaktur Sub Sektor Farmasi yang terdaftar di Bursa Efek Indonesia berjumlah 10 perusahaan, sedangkan sampel untuk penelitian ini berjumlah 8 Perusahaan Farmasi. Teknik pengumpulan data dalam penelitian ini adalah dengan menggunakan teknik dokumentasi dan studi pustaka. Hasil penelitian menunjukkan, 1) debt to aset ratio tidak berpengaruh signifikan terhadap Kinerja Keuangan, 2) debt to equity ratio berpengaruh signifikan terhadap Kinerja Keuangan, 3) tata kelola perusahaan berpengaruh signifikan terhadap Kinerja Keuangan, 4) debt to aset ratio, debt to equity ratio dan tata kelola perusahaan secara simultan berpengaruh signifikan terhadap Kinerja Keuangan. koefisien determinasi $\left(\mathrm{R}^{2}\right)$ yang diperoleh sebesar 0,637, berarti bahwa kemampuan variabel independen dalam mendiskrispsikan variabel dependen adalah sebesar $63,7 \%$, sedangkan sisanya $(100 \%-63,7 \%=36,3 \%)$. Sebesar 36,3\% didiskripsikan oleh faktor-faktor lain di luar variabel dalam persamaan regresi.

Kata Kunci : Rasio Leverage, Debt to Aset Ratio, Debt to Equity Ratio, Tata Kelola Perusahaan, Kinerja Keuangan

\begin{tabular}{lll}
\hline A. PENDAHULUAN & persaingan antara perusahaan- \\
Perkembangan politik, sosial, & perusahaan yang semakin meningkat. \\
teknologi dan perekonomian di & Hal ini menuntut perusahaan untuk \\
Indonesia dari tahun ke tahun semakin & lebih optimal dalam beroperasi \\
meningkat. Perkembangan dunia bisnis & sehingga dapat terus meningkatkan
\end{tabular}

juga semakin maju dan menimbulkan 
kemampuan bersaing demi kelangsungan hidupnya.

Perusahaan farmasi adalah perusahaan bisnis komersial yang fokus dalam meneliti, mengembangkan dan mendistribusikan obat, terutama dalam hal kesehatan. Perusahaan ini di Indonesia merupakan perusahaan besar yang mampu menyumbang (PDB) Produk Domestik Bruto sebesar 6,3\% pertahun (M.Fithrul Mubarok, 2017). Farmasi merupakan kebutuhan sekunder masyarakat. Sektor industri ini mengalami pertumbuhan paling tajam yang dipicu oleh menurunnya perilaku hidup sehat masyarakat Indonesia. Hal ini mengakibatkan industri ini terus berkembang, sehingga perusahaan yang melakukan bisnis ini pun semakin bertambah yang mengakibatkan persaingan-persaingan ketat diantara perusahaan.

Kemampuan perusahaan agar dapat bersaing sangat ditentukan oleh kinerja perusahaan, terutama di bagian kinerja keuangan. Kinerja keuangan merupakan gambaran dari pencapaian keberhasilan perusahaan, dapat diartikan sebagai hasil yang telah dicapai atas berbagai aktivitas yang telah dilakukan sehingga dapat dilihat sudah sejauh mana suatu perusahaan telah melaksanakan dan telah menggunakan aturan - aturan pelaksanaan keuangan secara baik dan benar (Fahmi, 2011:2). faktor - faktor yang dapat memperbaiki kinerja keuangan sangat penting untuk diketahui oleh perusahaan.

Debt to aset ratio merupakan rasio keuangan yang digunakan untuk mengukur seberapa besar aktiva perusahaan yang dibiayai oleh utang atau seberapa besar utang perusahaan berpengaruh terhadap pengelolaan aktiva. Debt to equity ratio merupakan rasio yang digunakan untuk mengukur seberapa besar total aset yang dimiliki perusahaan dibiayai dengan penggunaan utang, sehingga dengan rasio ini dapat mengetahui seberapa bagus kondisi suatu perusahaan. Apabila rasio utang semakin rendah, maka semakin bagus kondisi perusahaan tersebut karena hanya sebagian kecil aset perusahaan yang dibiayai dengan utang. Tata kelola perusahaan dimaksudkan untuk mengatur hubungan dan mencegah terjadinya kesalahan dalam strategi korporasi dan untuk memastikan kesalahan yang terjadi dapat segera diperbaiki (Muharam, 2012). Tata kelola perusahaan juga mepengaruhi pengarahan, pengelolaan, serta 
pengontrolan suatu perusahaan yang bertujuan dapat mewujudkan pengelolaan bisnis yang sesuai dengan prinsip - prinsip tata kelola perusahaan yang baik.

Berdasarkan latar belakang diatas dapat dilihat betapa pentingnya pengaruh rasio leverage berupa debt to aset ratio dan debt to equity ratio, tata kelola perusahaan terhadap kinerja keuangan suatu perusahaan, maka penulis melakukan suatu penelitian yang berjudul, "Pengaruh Debt To Aset Ratio, Debt To Equity Ratio dan Tata Kelola Perusahaan Terhadap Kinerja Keuangan Pada Perusahaan Manufaktur Subsektor Farmasi Yang Terdaftar Di Bursa Efek Indonesia Periode 20132017'.

Tujuan Penelitian

1. Menguji pengaruh debt to aset ratio terhadap kinerja keuangan pada perusahaan sub sektor farmasi yang terdaftar di Bursa Efek Indonesia tahun 2013 sampai dengan 2017.

2. Menguji pengaruh debt to equity ratio terhadap kinerja keuangan pada perusahaan sub sektor farmasi yang terdaftar di Bursa Efek Indonesia tahun 2013 sampai dengan 2017.
3. Menguji pengaruh tata kelola perusahaan terhadap kinerja keuangan pada perusahaan sub sektor farmasi yang terdaftar di Bursa Efek Indonesia tahun 2013 sampai dengan 2017.

4. Menguji secara simultan pengaruh debt to aset ratio, debt to equity ratio dan tata kelola perusahaan terhadap kinerja keuangan pada perusahaan sub sektor farmasi yang terdaftar di Bursa Efek Indonesia tahun 2013 sampai dengan 2017.

\section{B. TINJAUAN PUSTAKA}

\section{Penelitian Terdahulu}

Penelitian Ali (2012) dengan judul "Pengaruh Good Corporate Governance Dan Leverage Terhadap Kinerja Keuangan Perbankan Di BEI Tahun 2007-2010", menunjukkan bahwa secara parsial Ukuran dewan direksi, ukuran dewan komisaris dan komite audit tidak berpengaruh terhadap kinerja perusahaa, sedangkan leverage berpengaruh terhadap kinerja perusahaan. Secara simultan ukuran dewan direksi, ukuran dewan komisaris, komite audit dan leverage berpengaruh positif terhadap kinerja perusahaan.

Penelitian Augtiah (2017) dengan judul "Pengaruh Good Corporate Governance Dan Leverage Terhadap Kinerja Keuangan 
Pada Bank Umum Yang Terdaftar Di Bei Tahun 2013-2015", menunjukan bahwa secara parsial Dewan komisaris Independen, Komisaris Independen, dan Leverage secara bersama-sama berpengaruh signifikan terhadap Kinerja Keuangan Bank (ROA). Secara parsial Dewan Komisaris Independen berpengaruh signifikan terhadap Kinerja Keuangan Bank (ROA) sedangkan Komisaris Independen dan Leverage tidak berpengaruh tidak signifikan terhadap Kinerja Keuangan Bank (ROA).

Penelitian Efendi (2017) dengan judul "Pengaruh Debt To Equity Ratio (Der) Dan Debt To Asset Ratio (Dar) Terhadap Kinerja Perusahaan Di Sektor Keuangan Yang Terdaftar Di Bursa Efek Indonesia", menunjukan bahwa DER berpengaruh terhadap Kinerja Keuangan (ROA dan ROE), sedangkan DAR berpengaruh terhadap ROA dan tidak berpengaruh terhadap ROE.

\section{Kinerja Keuangan}

Kinerja keuangan merupakan sesuatu yang dihasilkan suatu organisasi dalam periode waktu tertentu dengan standar yang ditetapkan (Zarkasyi, 2008:48). Penilaian terhadap kinerja keuangan perusahaaan merupakan suatu kegiatan yang sangat penting karena berdasarkan penilaian tersebut dapat dijadikan sebagai ukuran keberhasilan perusahaan selama perode waktu tertentu. Semakin baik kinerja keuangan perusahaan maka perusahaan bisa dikatakan semakin berhasil.

$\mathrm{ROA}=\frac{\text { Laba Bersih }}{\text { Total Aktiva }} X 100 \%$

\section{Debt to Assets Ratio (DAR)}

Rasio ini mengukur berapa besar aktiva perusahaan yang dibiayai oleh kreditur atau dengan kata lain jumlah aset yang dibiayai oleh utang.

$\mathrm{DAR}=\frac{\text { Total Hutang }}{\text { Total Aktiva }} X 100 \%$

\section{Debt to Equity Ratio (DER)}

Rasio ini menunjukkan kemampuan perusahaan untuk memenuhi kewajibannya dengan menggunakan modal yang ada. Semakin tinggi debt to equity ratio (DER). semakin besar pula risiko keuangannya, ataupun sebaliknya semakin rendah rasio ini akan semakin rendah risiko keuangannya.

$\mathrm{DER}=\frac{\text { Total Hutang }}{\text { Total Equity }} X 100 \%$

Tata kelola perusahaan merupakan salah satu dari pengendalian perusahaan yang mengatur kebijakan-kebijakan yang ada didalam perusahaan dan sangat mempengaruhi kinerja keuangan 
perusahaan. Tujuan penerapan GCG

(Good Corporate Governance) pada BUMN untuk memaksimalkan kinerja dan mendorong pengelolaan BUMN secara profesional, serta turut menyukseskan program privatisasi BUMN. Manfaat penerapan GCG adalah untuk meningkatkan kinerja perusahaan, meminimalkan pembiayaan dalam perusahaan dan meningkatkan kepercayaan investor untuk menanamkan modalnya dalam perusahaan.

$\mathrm{TKP}=\frac{\sum \text { dewan komisaris independen }}{\sum \text { dewan komisaris perusahaan }} X 100 \%$

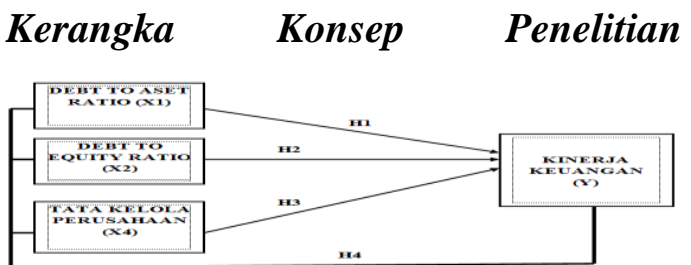

Gambar Kerangka Konsep Penelitian

Berdasarkan kajian teori dan kerangka pikir tersebut, maka dapat dirumuskan hipotesis.

H1: Debt to aset ratio berpengaruh terhadap kinerja keuangan perusahaan.

H2: Debt to equity ratio berpengaruh terhadap kinerja keuangan perusahaan

H3: Tata kelola perusahaan berpengaruh terhadap kinerja keuangan.
H4: Debt to aset ratio, debt to equity ratio dan Tata Kelola Perusahaan secara simultan berpengaruh terhadap kinerja keuangan.

\section{METODE PENELITIAN}

\section{Rancangan penelitian}

Jenis penelitian yang dilakukan adalah peneliti menggunakan pendekaan kuantitatif, pendekatan kuantitatif merupakan bentuk analisa data yang berupa angka - angka dengan menggunakan perhitungan statistik. Populasi dalam penelitian ini adalah seluruh perusahaan manufaktur subsektor farmasi yang terdaftar di Bursa Efek Indonesia selama periode 2013 sampai 2017 yaitu sebanyak 10 perusahaan, sedangkan sampel dikumpulkan dengan cara purposive sampling dan diperoleh 8 perusahaan.

\section{Sumber data}

Peneliti melakukan penelitian pada perusahaan manufaktur subsektor farmasi yang terdaftar di Bursa Efek Indonesia (BEI) selama periode 20132017 dengan pengamatan data dilakukan di www.idx.co.id, Index Capital Market Directory (ICMD) serta annual report. 


\section{Teknik Pengumpulan Data}

Teknik pengumpulan data dalam penelitian ini adalah dengan menggunakan teknik dokumentasi dan studi pustaka.

\section{Analisis Data}

Penelitian ini menggunakan Analisis Statistik Deskriptif, Uji Asumsi Klasik yang terdiri dari : Normalitas, Multikolinearitas, Autokorelasi dan Heteroskedastisitas, Analisis Regresi Liner Berganda dan Uji Hipotesis yang berupa Uji t, Uji $F$ dan $U j i R^{2}$ dalam menguji pengaruh variabel bebas terhadap variabel terikat.

\section{Analisis Statistik Deskriptif}

Analisis statistik deskriptif berupa gambaran atau deskripsi suatu data yang berkaitan untuk mengetahui nilai mean, nilai maksimum, nilai minimum, standard deviasi (Ghozali, 2011:19).

\section{Uji Asumsi Klasik}

\section{Uji Normalitas}

Uji normalitas bertujuan menguji apakah dalam metode regresi, variabel dependen dan variabel independen keduanya mempunyai distribusi normal atau tidak (Ghozali,
2013:160). Metode yang digunakan dalam pengujian kenormalan data yang digunakan adalah metode grafik (Histogram dan probability plot) dan metode pengujian Kolmogorove Smirnov.

Kriteria pengujian berdasarkan metode grafik histogram yaitu: dikatakan berdistribusi normal, apabila data menyebar disekitar garis diagonal dan mengikuti arah garis diagonal atau grafik histogramnya, begitu sebaliknya. Kriteria pengujian berdasarkan metode grafik probability plot yaitu jika titiktitik terlihat mengikuti dan mendekati garis diagonalnya maka dapat dikatakan bahwa berdistribusi normal, sedangkan jika titik-titik menjauh atau tersebar tidak mengikuti garis diagonal maka hal ini menunjukkan bahwa nilai residual berdistribusi normal. Kriteria pengujian berdasarkan metode Kolmogorov Sminov Jika nilai signifikansi atau nilai probabilitas $>0,05$ maka data terdistribusi normal dan jika nilai signifikansi atau nilai probabilitas $<0,05$ maka data tidak terdistribusi normal.

\section{Uji Multikolinearitas}

Uji multikoloniearitas ini bertujuan untuk mengetahui apakah tiap-tiap variabel bebas berhubungan 
secara linear atau apakah model ditemukan adanya korelasi antar variabel bebas (independen). Model regresi yang baik seharusnya tidak terjadi korelasi diantara variabel independen. Kriteria pengukurannya Jika tolerance $>0,10$ dan VIF $<10$, maka tidak terjadi multikolinieritas, dan Jika tolerance $<0,10$ dan $\mathrm{VIF}>10$, maka terjadi multikolinieritas.

\section{Uji Autokorelasi}

Uji autokorelasi bertujuan untuk menguji apakah dalam model regresi linear ada korelasi antara kesalahan pengganggu pada periode tertentu dengan kesalahan pengganggu pada periode sebelumnya(Ghozali,2012:110). Ada beberapa cara yang dapat digunakan untuk mendeteksi ada tidaknya autokorelasi yaitu Uji Durbin Watson dan Uji Runs Test.

Tabel 1. Kriteria pengukurannya Durbin

\section{Waston}

\begin{tabular}{|l|l|}
\hline Nilai hasil perhitungan & \multicolumn{1}{|c|}{ Kriteria } \\
\hline $0-1,046$ & Autokorelasi positif \\
\hline $1,046-1,535$ & Keraguan \\
\hline $1,535-2,465$ & Bebas autokorelasi \\
\hline $2,465-2,954$ & Keraguan \\
\hline $2,954-4$ & Autokorelasi negatif \\
\hline
\end{tabular}

Sumber: Chandra 2008

Kriteria pengujian Run Test, jika nilai asymp.sig (2-tailed) lebih besar dari 0,05 maka tidak terjadi autokorelasi. Jika nilai asymp.sig (2tailed) lebih kecil dari 0,05 maka terdapat masalah autokorelasi.

\section{Uji Heteroskedastisitas}

Uji heteroskedastisitas bertujuan menguji apakah dalam model regresi terjadi ketidaksamaan variance dari residual satu pengamatan ke pengamatan yang lain (Ghozali, 2012:139). Model regresi yang baik adalah tidak terjadi heteroskedastisitas.

Kriteria pengukurannya dapat dilihat dalam grafik scatterplot yaitu Jika ada pola tertentu, seperti titik-titik yang ada membentuk pola tertentu yang teratur (bergelombang, melebar kemudian menyempit), maka mengindikasikan telah terjadi heteroskedastisitas dan Jika tidak ada pola yang jelas, serta titik-titik menyebar di atas dan di bawah angka 0 pada sumbu Y, maka tidak terjadi heteroskedastisitas

\section{Analisis Regresi Linier Berganda}

Analisis regresi linier berganda adalah hubungan secara linear antara dua atau lebih variabel independen $\left(\mathrm{X}_{1}\right.$, $\left.\mathrm{X}_{2}, \ldots . \mathrm{X}_{\mathrm{n}}\right)$ dengan variabel dependen 
(Y). Analisis ini untuk mengetahui arah hubungan antara variabel independen dengan variabel dependen apakah masing-masing variabel independen berhubungan positif atau negatif dan untuk memprediksi nilai dari variabel dependen apabila nilai variabel independen mengalami kenaikan atau penurunan. Data yang digunakan biasanya berskala interval atau rasio.

Persamaan regresi linear berganda sebagai berikut

$\mathrm{KK}=\alpha 0+\beta \cdot \mathrm{DAR}+\beta \cdot \mathrm{DER}+\beta \cdot \mathrm{TKP}+\mathrm{e}$

$\mathrm{KK} \quad=$ Kinerja Keuangan

$\alpha 0 \quad=$ Konstanta

$\mathrm{DAR}=$ Debt to aset ratio

DER = Debt to equity ratio

TKP = Tata Kelola Perusahaan

$\beta=$ Koefisien regresi (nilai peningkatan ataupun penurunan

$\varepsilon=$ Error term

\section{Uji t (Parsial)}

Uji parsial dilakukan untuk mengetahui signifikan pengaruh dari variabel bebas terhadap variabel terikat (Ghozali, 2012:98).

Kriteria pengujian uji t yaitu jika nilai signifikansi < 0,05 atau 5\% berarti variabel bebas mempunyai pengaruh yang signifikan terhadap variabel terikat yaitu Kinerja Keuangan, sedangkan jika nilai signifikansi > 0,05 atau 5\% maka variabel bebas tidak terdapat pengaruh yang signifikan terhadap variabel terikat yaitu Kinerja Keuangan.

\section{Uji F (Simultan)}

Uji $F$ adalah uji untuk melihat bagaimana pengaruh semua variabel bebasnya secara bersama-sama terhadap variabel terikatnya.

Menurut Ghozali (2012:98) Dasar pengambilan keputusannya yaitu Jika $\mathrm{F}$ hitung> dari $F$ tabel dan nilai signifikansi<0,05, maka dapat diartikan bahwa variabel independen berpengaruh terhadap variabel dependen (Ho ditolak dan Ha diterima), Sedangkan Jika F hitung $<\mathrm{F}$ tabel dan nilai signifikansi>0,05, maka dapat diartikan bahwa variabel independen tidak berpengaruh terhadap variabel dependen (Ho diterima dan Ha ditolak).

\section{Uji $\mathbf{R}^{2}$ (Koefisien Determinasi)}

Uji koefisien determinasi pada penelitian ini betujuan untuk mengukur seberapa jauh kemampuan model dalam menerangkan variasi variabel dependen (Ghozali, 2012:97). Semakin tinggi $\mathrm{R}^{2}$ maka semakin besar proporsi dari total variasi dari total variasi variabel 
dependen yang dapat dijelaskan oleh variabel dependen (Ghozali, 2013:46).

\section{HASIL DAN PEMBAHASAN}

\section{Analisis Statistik Deskriptif}

Tabel 1. Analisis Statistik Deskriptif

\begin{tabular}{|l|l|l|l|l|}
\hline & MIN & MAX & Mean & $\begin{array}{l}\text { Std. } \\
\text { Deviation }\end{array}$ \\
\hline DAR (X1) & 7,07 & 69,12 & 33,4153 & 15,91244 \\
\hline DER(X2) & 7,43 & 190,62 & 55,9613 & 43,64047 \\
\hline $\begin{array}{l}\text { Tata } \\
\text { Kelola } \\
\text { Perusaha } \\
\text { an (X3) }\end{array}$ & 33,33 & 60,00 & 40,3322 & 8,62039 \\
\hline $\begin{array}{l}\text { Kinerja } \\
\text { Keuangan } \\
\text { (Y) }\end{array}$ & $-4,19$ & 25,62 & 10,0355 & 7,44165 \\
\hline
\end{tabular}

Sumber: Hasil Output SPSS 2018

Dari hasil pengujian statistik deskriptif diatas dapat dijelaskan sebagai berikut :

DAR nilai minimum sebesar 7,07; maksimum sebesar 69,12; nilai mean (rata-rata) sebesar 33,4152 dan standar deviasi 15,91244 . Perusahaan yang memiliki jumlah DAR terendah adalah Industri Jamu \& Farmasi Sido Muncul (SIDO) pada tahun 2015 yaitu sebesar 7,07, sedangkan perusahaan yang memiliki jumlah DAR tertinggi adalah Industri Jamu \& Farmasi Sido Muncul (SIDO) pada tahun 2014 sebesar 69,12.

DER nilai minimum sebesar 7,43; maksimum sebesar 190,62; nilai mean sebesar 55,9612 dan standar deviasi 43,64047. Perusahaan yang memiliki jumlah DER terendah adalah Industri Jamu \& Farmasi Sido Muncul (SIDO) pada tahun 2014 yaitu sebesar
7,43, sedangkan perusahaan yang memiliki jumlah DER tertinggi adalah Industri Indofarma (Persero) Tbk (INAF) pada tahun 2017 sebesar 190,62 .

TKP nilai minimum sebesar 3,33; maksimum sebesar 60,00; nilai mean sebesar 40,3323 dan standar deviasi 8,62039. Perusahaan yang memiliki jumlah DKI terendah adalah Darya Varia Laboratoria Tbk (DVLA) pada tahun 2015, Indofarma (Persero) Tbk (INAF) pada tahun 2014-2017, Kalbe Farma Tbk (KLBF) pada tahun 2013-2014, Merck Indonesia Tbk (MERK) tahun 2013-2017, Pyridam Farma Tbk (PYFA) tahun 2013-2014, Industri Jamu \& Farmasi dan Sido Muncul Tbk (SIDO) tahun 2013-2017, yaitu sebesar 3,33, sedangkan perusahaan yang memiliki jumlah TKP tertinggi adalah Tempo Scan Pasific Tbk (TSPC) tahun 2013-2014 dan 2016-2017 sebesar 60,00.

Kinerja Keuangan nilai minimum sebesar 4,19; maksimum sebesar 25,62; nilai mean sebesar 10,0355 dan standar deviasi 7,44165. Perusahaan yang memiliki jumlah Kinerja Keuangan terendah adalah Indofarma (Persero) Tbk (INAF) tahun 
2013 yaitu sebesar -4,19, sedangkan perusahaan yang memiliki jumlah Kinerja Keuangan tertinggi adalah Merck Indonesia Tbk (MERK) tahun 2014 sebesar 25,62.

\section{Uji Asumsi Klasik}

\section{Uji Normalitas}

Tabel 2. Uji Normalitas Kolmogorov Sminov

\begin{tabular}{|l|l|r|}
\hline \multicolumn{2}{|c|}{} & \multicolumn{2}{|c|}{$\begin{array}{c}\text { Unstandardized } \\
\text { Residual }\end{array}$} \\
\hline \multirow{2}{*}{$\mathrm{N}$} & Mean \\
\hline $\begin{array}{l}\text { Normal } \\
\text { Parameters }\end{array}$ & 40 \\
\cline { 2 - 3 } & $\begin{array}{l}\text { Std. } \\
\text { Deviation }\end{array}$ &, 0000000 \\
\hline $\begin{array}{l}\text { Most Extreme } \\
\text { Differences) }\end{array}$ & Absolute & 4,30923366 \\
\cline { 2 - 3 } & Positive &, 080 \\
\cline { 2 - 3 } & Negative &, 080 \\
\hline Test Statistic & &,- 055 \\
\hline Asymp. Sig. (2-tailed) &, 080 \\
\hline
\end{tabular}

Sumber: Hasil Output SPSS 2018

Berdasarkan tabel diatas menunjukkan besarnya nilai probabilitas adalah $0,200>0,05$ sehingga dikatakan bahwa data berdistribusi normal.

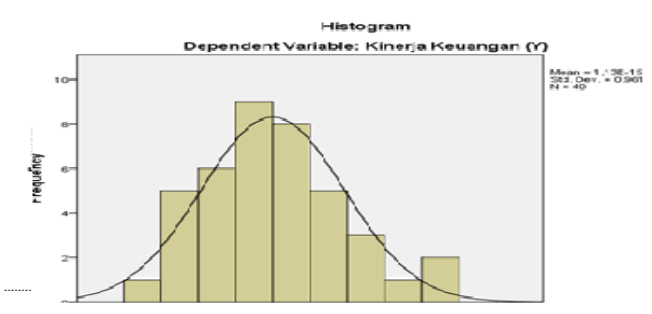

Gambar 1.Gambar Histogram

Berdasarkan grafik histogram diatas dapat disimpulkan bahwa grafik histogram tersebut menyebar disekitar garis diagonal dan mengikuti arah garis diagonal atau grafik histogram, sehingga dapat dikatakan bahwa data berdistribusi normal.

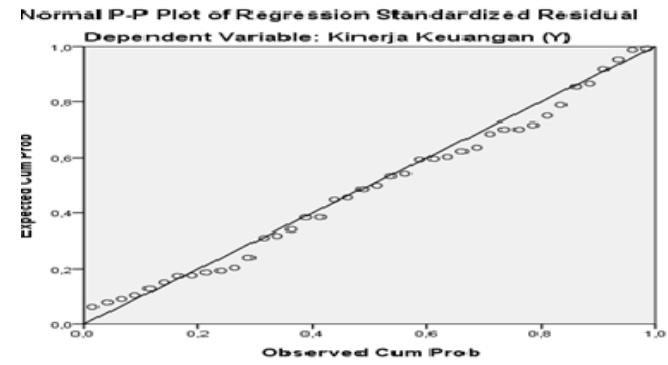

Gambar 2.Gambar Probability Plot

Berdasarkan gambar grafik probability plot diatas dapat dilihat bahwa, plot-plot mengikuti garis fit line, titik-titik dalam grafik scatterplot diatas tersebar mengikuti garis miring (diagonal) dan tidak terpancar jauh, maka dari hasil tersebut dapat disimpulkan bahwa variabel berdistribusi normal.

\section{Uji Multikolinearitas}

Tabel 3. Uji Multikolinearitas

\begin{tabular}{|l|r|r|}
\hline & Tolerance & \multicolumn{1}{|c|}{ VIF } \\
\hline \multicolumn{1}{|c|}{ (Constant) } &, 334 & \\
\hline DAR (X1) &, 331 & 3,995 \\
\hline DER (X2) &, 982 & 1,022 \\
\hline $\begin{array}{l}\text { Tata Kelola } \\
\text { Perusahaan (X3) }\end{array}$ & & \\
\hline
\end{tabular}

Sumber: Hasil Output SPSS 2018

Berdasarkan hasil VIF menunjukkan DAR sebesar 2,995, DER sebesar 3,022, Tata Kelola Perusahaan sebesar 1,018 dan hasil tolerance menunjukkan Debt to Aset 
Ratio sebesar 0,334, Debt to Equity

Ratio sebesar 0,331, Tata Kelola

Perusahaan sebesar 0,982 yang berarti dapat dikatakan tidak terjadi gejala multikolinearitas dikarenakan nilai VIF $<10$ dan nilai toleransi $>0,10$.

\section{Uji Autokorelasi}

Tabel 4. Uji Autokorelasi

\begin{tabular}{|c|c|c|c|c|r|}
\hline $\begin{array}{c}\text { Mode } \\
1\end{array}$ & $\mathrm{R}$ & $\begin{array}{c}\mathrm{R} \\
\text { Squa } \\
\mathrm{re}\end{array}$ & $\begin{array}{c}\text { Adjuste } \\
\mathrm{dR} \\
\text { Square }\end{array}$ & $\begin{array}{c}\text { Sig. F } \\
\text { Chang } \\
\mathrm{e}\end{array}$ & $\begin{array}{c}\text { Durbin } \\
\text { Wasto } \\
\mathrm{n}\end{array}$ \\
\hline 1 &, $815^{\mathrm{a}}$ &, 665 &, 637 &, 000 & $\begin{array}{r}2,32 \\
5\end{array}$ \\
\hline
\end{tabular}

Apabila dilihat dari hasil pengujian diperoleh nilai Durbin Waston sebesar 2,325, nilai tersebut berdasarkan kriteria pengujian Durbin Waston (Chandra, 2008) terletak diantara 1,535-2,465 sehingga dapat dikatakan bahwa bebas dari autokorelasi.

Tabel 5. Run Test

\begin{tabular}{|l|r|}
\hline & \multicolumn{2}{|l|}{$\begin{array}{l}\text { Unstandardized } \\
\text { Residual }\end{array}$} \\
\hline Test Value $^{\mathrm{a}}$ &,- 08996 \\
\hline Cases $<$ Test Value & 20 \\
\hline Cases $>=$ Test Value & 20 \\
\hline Total Cases & 40 \\
\hline Number of Runs & 20 \\
\hline Z &,- 160 \\
\hline Asymp. Sig. (2-tailed) &, 873 \\
\hline
\end{tabular}

Sumber: Hasil Output SPSS 2018

Nilai asymp. Sig (2-tailed) lebih besar dari $0,05(0,873>0,05)$ sehingga dapat disimpulkan bahwa model regresi tidak terdapat masalah autokorelasi.
Uji Heteroskedastisitas

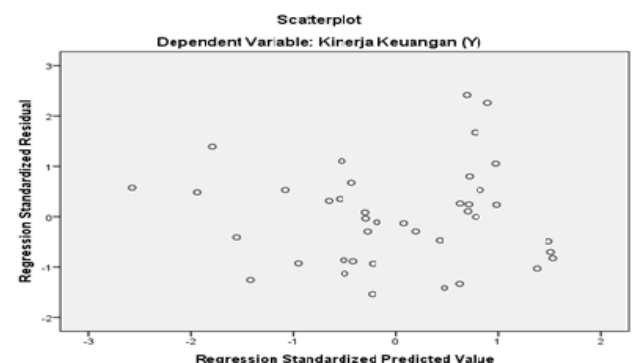

Gambar 3.Gambar Scattetplot

Dari pola grafik scatterplot tersebut dapat dilihat bahwa pola grafik berbentuk acak, serta tersebar baik diatas maupun dibawah angka 0 pada sumbu Y, maka dapat disimpulkan bahwa tidak terdapat gejala heteroskedastisitas.

\section{Uji Analisis Regresi Linier Berganda}

Tabel 6. Analisis Regresi Linier Berganda

\begin{tabular}{|c|r|r|r|r|}
\hline Variabel & \multicolumn{1}{l|}{ B } & \multicolumn{1}{|c|}{$\begin{array}{c}\text { Etd. } \\
\text { Error }\end{array}$} & \multicolumn{1}{|c|}{ t } & Sig. \\
\hline (Constant) & 29,534 & 3,892 & 7,588 &, 000 \\
\hline DAR (X1) &,- 082 &, 078 & $-1,050$ &, 301 \\
\hline DER (X2) &,- 110 &, 029 & $-3,851$ &, 000 \\
\hline $\begin{array}{l}\text { Tata Kelola } \\
\text { Perusahaan } \\
\text { (X3) }\end{array}$ &,- 263 &, 084 & $-3,124$ &, 004 \\
\hline
\end{tabular}

Sumber: Hasil Output SPSS 2018

Berdasarkan tabel diatas, Maka persamaan regresi linier berganda yang dapat diformulasikan adalah sebagai berikut :

$\mathrm{KK}=29,534-0,082 \cdot \mathrm{DAR}-0,110 . \mathrm{DER}$

$-0,263 . T K P+\mathrm{e}$

Keterangan $=$ 
$\mathrm{KK}=$ Kinerja Keuangan

$\mathrm{DAR}=$ Debt to Aset ratio

DER = Debt to Equity ratio

$\mathrm{TKP}=$ Tata Kelola Perusahaan

e $=$ Error term

Persamaan regresi tersebut dapat diuraikan sebagai berikut:

a. Konstanta $(\alpha)$ dari persamaan regresi sebesar 29,534 menyatakan bahwa jika nilai variabel independen bernilai nol, maka nilai Kinerja Keuangan sebesar nilai konstanta yaitu 29,534.

b. DAR terhadap Kinerja Keuangan Nilai Koefisien regresi Debt to Aset Ratio (X1) sebesar -0,082 memiliki arti bahwa setiap peningkatan DAR 1 satuan, maka Kinerja Keuangan akan mengalami penurunan sebesar $-0,082$ dengan asumsi bahwa nilai koefisien variabel independen lainnya tetap atau sama dengan dengan nol.

c. DER terhadap Kinerja Keuangan Koefisien regresi Debt to Equity Ratio (X2) sebesar -0,110 memiliki arti bahwa setiap peningkatan DER 1 satuan, maka Kinerja Keuangan akan mengalami penurunan sebesar -0,110 dengan asumsi bahwa nilai koefisien variabel independen lainnya tetap atau sama dengan dengan nol.

d. TKP terhadap Kinerja Keuangan Koefisien regresi Tata Kelola Perusahaan (X3) sebesar -0,263 memiliki arti bahwa setiap peningkatan TKP 1 satuan, maka Kinerja Keuangan akan mengalami penurunan sebesar -0,263 dengan asumsi bahwa nilai koefisien variabel independen lainnya tetap atau sama dengan dengan nol.

Tabel 7. Uji t (Parsial)

\begin{tabular}{|l|c|c|}
\hline Variabel & T & Sig. \\
\hline \multicolumn{1}{|c|}{ (Constant) } & 7,588 &, 000 \\
\hline DAR (X1) & $-1,050$ &, 301 \\
\hline DER (X2) & $-3,851$ &, 000 \\
\hline Tata Kelola & & \\
Perusahaan (X3) & $-3,124$ &, 004 \\
\hline
\end{tabular}

Sumber: Hasil Output SPSS 2018

a. Pengaruh DAR terhadap Kinerja Keuangan

Berdasarkan tabel diperoleh nilai signifikansi $0,301>0,050$, maka dapat disimpulkan bahwa secara parsial DAR tidak berpengaruh signifikan terhadap kinerja keuangan. Ho diterima $\mathrm{H} 1$ ditolak

b. Pengaruh DER terhadap Kinerja Keuangan

Berdasarkan tabel diperoleh nilai t-signifikansi $\quad 0,000<0,050$, 
maka dapat disimpulkan bahwa secara parsial DER berpengaruh signifikan terhadap kinerja keuangan. Ho diterima $\mathrm{H} 2$ ditolak

c. Pengaruh TKP terhadap Kinerja Keuangan

Berdasarkan tabel diperoleh nilai signifikansi $\quad 0,004<0,050$, maka dapat disimpulkan bahwa secara parsial TKP berpengaruh signifikan terhadap kinerja keuangan. Ho diterima H3 ditolak.

Tabel 8. Uji F (Simultan)

\begin{tabular}{|l|c|c|c|c|}
\hline Variabel & $\begin{array}{c}\text { Sum of } \\
\text { Square } \\
\text { S }\end{array}$ & $\begin{array}{c}\text { Mean } \\
\text { Squar } \\
\text { e }\end{array}$ & F & Sig \\
\hline Regresion & 1435,535 & 478,512 &, 000 &, $000^{\mathrm{b}}$ \\
\hline Residual & 724,210 & 20,117 & & \\
\hline Total & 2159,745 & & & \\
\hline
\end{tabular}

Sumber: Hasil Output SPSS 2018

Berdasarkan perhitungan yang ditunjukkan pada tabel diatas dapat dilihat nilai signifikansi sebesar 0,000 lebih kecil dari $0,05(0,000<0,05)$ dan nilai $\mathrm{F}$ hitung pada tabel sebesar23,786 dan nilai $\mathrm{F}$ tabel sebesar 2,86 (F hitung $23,786>$ F tabel 2,86), sehingga dapat disimpulkan bahwa secara simultan DAR, DER, dan TKP berpengaruh signifikan terhadap Kinerja Keuangan dengan kata lain Ho ditolak H4 diterima.

\section{Pembahasan}

Penelitian yang dilakukan untuk mengetahui pengaruh debt to aset ratio, debt to equity ratio dan tata kelola perusahaan terhadap Kinerja Keuangan pada Perusahaan Manufaktur Sub Sektor Farmasi yang terdaftar di Bursa Efek Indonesia untuk periode pengamatan 2013-2017. Dari hasil penelitian diperoleh hasil bahwa :

a. Pengaruh Debt to Aset Ratio secara parsial terhadap kinerja keuangan.

Dari hasil pengujian diperoleh nilai signifikansi $0,301>0,050$, maka dapat disimpulkan bahwa variabel DAR secara parsial tidak berpengaruh signifikan terhadap kinerja keuangan. Ho diterima $\mathrm{H}_{1}$ ditolak.

Debt to asset ratio tidak berpengaruh terhadap kinerja keuangan, yang artinya bahwa pemenuhan kebutuhan perusahaan tidak tergantung oleh hutang. Sejalan dengan ungkapan Fahmi (2014:63) bahwa semakin rendah DAR maka semakin baik karena aman bagi kreditor saat likuidasi. Berdasarkan teori DAR dijelaskan bahwa semakin tinggi debt to aset ratio (DAR) menunjukkan semakin besar jumlah modal pinjaman yang digunakan didalam menghasilkan keuntungan bagi perusahaan. Perusahaan yang memiliki 
utang dalam kategori relatif tinggi cenderung dapat menurunkan tingkat profitabilitasnya. Hal ini disebabkan karena perusahaan wajib membayar bunga atas pinjaman yang dilakukan. Sehingga dapat disimpulkan bahwa semakin tinggi debt to aset ratio akan menyebabkan kinerja keuangan berupa return on aset semakin kecil sehingga lebih baik perusahaan memiliki DAR yang rendah.

Hasil Penelitian ini sejalam dengan penelitian yang dilakukan oleh Utama (2014), Maulita (2018), Widiyanti (2015), Asiah (2011) dan Kusuma (2016) yang menunjukkan bahwa debt to aset ratio tidak berpengaruh signifikan terhadap Kinerja Keuangan

b. Pengaruh Debt to Equity Ratio secara parsial terhadap kinerja keuangan.

Dari hasil pengujian diperoleh nilai signifikansi sebesar $0,000<0,050$, maka dapat disimpulkan bahwa secara parsial DER berpengaruh signifikan terhadap kinerja keuangan. Ho ditolak $\mathrm{H}_{2}$ diterima.

Semakin tinggi DER menunjukkan semakin besar kepercayaan dari pihak luar, hal ini sangat memungkinkan meningkatkan kinerja perusahaan, karena dengan modal yang besar maka kesempatan untuk meraih tingkat keuntungan juga besar. Dengan demikian pengaruh DER terhadap ROA adalah positif. Hal tersebut didukung oleh pecking order theory yang menetapkan suatu urutan keputusan pendanaan dimana para manajer pertama kali akan memilih untuk menggunakan laba ditahan, kemudian hutang, dan modal sendiri eksternal sebagai pilihan terakhir (Brigham dan Houston, 2001:85)

Hasil Penelitian ini sama dengan penelitian yang dilakukan oleh Jatismara (2011), Efendi (2016), Utama (2014) dan Farihah (2016) dan Limin (2014) yang menunjukkan bahwa DER berpengaruh signifikan terhadap Kinerja Keuangan

c. Pengaruh Tata Kelola Perusahaan secara parsial terhadap kinerja keuangan.

Dari hasil pengujian nilai $\mathrm{t}$ signifikansi sebesar $0,004<0,050$, maka dapat disimpulkan bahwa secara parsial TKP berpengaruh signifikan terhadap kinerja keuangan. Ho ditolak $\mathrm{H}_{3}$ diterima.

Secara teori komisaris independen dapat bertindak sebagai penengah dalam suatu perselisihan yang terjadi antara 
para manajer internal dan mengawasi kebijakan direksi serta bertugas sebagai pemberi nasihat kepada direksi. Komisaris independen merupakan sebuah posisi yang baik untuk melaksanakan fungsi pengawasan terhadap pengelolaan perusahaan supaya tercipta suatu perusahaan yang good corporate governance, sehingga bisa meningkatkan kinerja perusahaan. jika perusahaan menerapkan prinsipprinsip GCG, maka laporan keuangan yang dihasilkan dapat diungkapkan secara transparan dan akurat, sehingga dapat membantu investor dan pihakpihak lain yang berkepentingan dalam suatu perusahaan untuk mengambil keputusan sehingga dapat meningkatkan kinerja keuangan.

Hasil penelitian ini sama dengan penelitian yang dilakukan oleh Isaura (2014), Tefanus (2011), Hutami (2014), Putra (2017) dan Hendratni (2018) yang menunjukkan bahwa TKP berpengaruh signifikan terhadap Kinerja Keuangan.

d. Pengaruh Debt to Aset Ratio, Debt to Equity Ratio dan Tata Kelola Perusahaan secara simultan terhadap kinerja keuangan.

Dari hasil pengujian nilai signifikansi sebesar 0,000 lebih kecil dari $0,05(0,000<0,05)$ dan nilai $\mathrm{F}$ hitung 23,786 > Ftabel 2,86, sehingga dapat disimpulkan bahwa secara simultan DAR, DER, dan TKP berpengaruh positif signifikan terhadap Kinerja Keuangan. Ho ditolak H4 diterima.

Semakin besar presentase pendanaan yang disediakan oleh ekuitas pemegang saham, semakin besar jaminan perlindungan yang didapat oleh investor atau kreditor perusahaan. Dapat disimpulkan bahwa semakin tinggi debt to aset ratio (DAR) dan debt to equity ratio (DER) semakin besar pula risiko keuangannya, ataupun sebaliknya semakin rendah rasio ini akan semakin rendah risiko keuangannya.Semakin tinggi dalam menerapkan tata kelola perusahaan akan semakin baik dalam meningkatkan kinerja keuangan perusahaan, dengan begitu perusahaan tersebut semakin efisien dalam menggunakan asetnya, berarti perusahaan tersebut dapat menghasilkan uang yang lebih banyak dengan investasi yang sedikit. Semakin baik praktik tata kelola yang diterapkan maka kinerja perusahaan juga akan meningkat.

Hasil penelitian ini sama dengan penelitian yang dilakukan oleh Augtiah 
(2017), Yulianawati (2014), Sa'ani (2008), Ali (2012) dan Sulistyani (2018).

\section{E. SIMPULAN}

Berdasarkan hasil penelitian dan pembahasan yang telah dikemukakan sebelumnya maka dapat diambil kesimpulan sebagai berikut :

a. Hipotesis Pertama $\left(\mathrm{H}_{1}\right)$ : menyatakan bahwa Debt to Aset Ratio berpengaruh terhadap Kinerja Keuangan

Berdasarkan penelitian dapat disimpulkan bahwa secara parsial Debt to Aset Ratio tidak berpengaruh signifikan terhadap Kinerja Keuangan, dibuktikan dengan nilai signifikansi 0,301>0,050, yang berarti Ho diterima $\mathrm{H}_{1}$ ditolak.

b. Hipotesis Kedua $\left(\mathrm{H}_{2}\right)$ : menyatakan bahwa Debt to Equity Ratio berpengaruh terhadap Kinerja Keuangan

Berdasarkan penelitian dapat disimpulkan bahwa secara parsial Debt to Equity Rasio berpengaruh signifikan terhadap Kinerja Keuangan, dibuktikan dengan nilai signifikansi $0,000<0,050$, yang berarti Ho ditolak $\mathrm{H}_{2}$ diterima.

c. Hipotesis Ketiga $\left(\mathrm{H}_{3}\right)$ : menyatakan bahwa Tata Kelola Perusahaan berpengaruh terhadap Kinerja

\section{Keuangan}

Berdasarkan penelitian dapat disimpulkan bahwa secara parsial Tata Kelola Perusahaan berpengaruh signifikan terhadap Kinerja Keuangan dibuktikan dengan nilai signifikansi sebesar $0,004<0,050$, yang berarti Ho ditolak $\mathrm{H}_{3}$ diterima.

d. Hipotesis Keempat $\left(\mathrm{H}_{4}\right)$ : menyatakan bahwa secara simultan Debt to Aset Ratio, Debt to Equity Ratio dan Tata Kelola Perusahaan berpengaruh signifikan terhadap Kinerja Keuangan

Berdasarkan penelitian dapat disimpulkan bahwa secara simultan in Debt to aset ratio, Debt to equity ratio dan Tata Kelola Perusahaan berpengaruh signifikan terhadap Kinerja Keuangan yang dibuktikan dengan nilai signifikansi sebesar $0,000<0,050$ dan nilai $\mathrm{F}$ hitung 23,786 > Ftabel 2,86, yang berarti Ho ditolak $\mathrm{H}_{4}$ diterima 


\section{DAFTAR PUSTAKA}

\section{Online Journal}

Afifah. (2017). Pengaruh Corporate Governance Terhadap Kinerja Keuangan Pada Perusahaan Perbankan Yang Terdaftar Di Bursa Efek Indonesia Tahun 2011-2014. Jurnal Ekonomi vol 3, No.4, pp. 305-360.

Afrianty. (2011). Skripsi Analisis Pengaruh Current Ratio, Total Assets Turnover, Debt to Equity Ratio, Sales dan Size Terhadap Return on Assets. Universitas Diponegoro Semarang.

Akbar. (2016). Pengaruh Debt to Asset Ratio dan Debt to Equity Ratio terhadap Return on Aset Pada Perusahaan Sektor Food \& Beverages Yang Terdaftar di Bursa Efek Indonesia.

Ali. (2012). Pengaruh Good Corporate Governance Dan Leverage Terhadap Kinerja Keuangan Perbankan Di BEI Tahun 2007-2010. Skripsi. Surakarta. Universitas Muhammadiyah Surakarta.

Augtiah. (2017). Skripsi. Pengaruh Good Corporate Governance Dan Leverage Terhadap Kinerja Keuangan Pada Bank Umum Yang Terdaftar Di Bei Tahun 2013-2015. Fakultas Ekonomi Dan Bisnis Universitas Muhammadiyah Surakarta.

Barus. (2013). Analisis Faktor-Faktor Yang Mempengaruhi Profitabilitas Pada Perusahaan Manufaktur Yang Terdaftar Di Bursa Efek Indonesia. Jurnal Wira Ekonomi Mikroskil Volume 3, Nomor 02, Oktober 2013.

Efendi. (2017). Skripsi Pengaruh Debt To Equity Ratio (Der) Dan Debt To Asset Ratio (Dar) Terhadap Kinerja Perusahaan Di Sektor Keuangan Yang Terdaftar Di Bursa Efek Indonesia. Akuntansi Manajerial Jurusan Manajemen Bisnis Politeknik Negeri Batam.

Hastuti. (2010). Analisis Pengaruh Periode Perputaran Persediaan, Periode Perputaran Hutang Dagang, Rasio Lancar, Leverage, Pertumbuhan Penjualan Dan Ukuran Perusahaan Terhadap Profitabilitas Perusahaan Perusahaan Manufaktur yang Terdaftar di BEI pada tahun 2006-2008. Skripsi. Fakultas Ekonomi Universitas Diponegoro.

Hendratni. (2018). Analisis Pengaruh Corporate Governance Terhadap Kinerja Keuangan Sektor Perbankan Yang Terdaftar Di Bei Tahun 2012-2016. Jurnal Riset Manajemen dan Bisnis (JRMB) Fakultas Ekonomi UNIAT Vol.3, No.1 Februari 2018: 37 - 52

Isaura. (2014). Pengaruh Tata Kelola Perusahaan Terhadap Kinerja Keuangan Pada Perusahaan Perbankan Yang Terdaftar Di Bursa Efek Indonesia. Jurnal Ekonom vol 14, No.3, Juli 2011.

Jatismara. (2011). Analisis pengaruh TATO, DER, Dividend, Sales dan Current Ratio terhadap Return On Asset, Skripsi, Universitas Diponegoro Semarang. 
Julita. (2012). "Pengaruh Debt to Equity Ratio dan Debt to Asset Ratio Pada Perusahaan Transformasi Yang Terdaftar di Bursa Efek Indonesia”. Jurnal Akuntansi.

Kusuma. (2016). Pengaruh DAR, Ukuran Perusahaan, Risiko, Pajak,Dan Likuiditas Terhadap Profitabilitas perusahaan Sektor Pertambangan Di Indonesia. BISMA Bisnis dan Manajemen -Volume 8 No. 2 Februari 2016

Limin. Pengaruh Current Ratio, Ukuran Perusahaan, dan DER Terhadap ROA Perusahaan Yang Tergabung Dalam Lq 45 Di Bursa Efek Indonesia. Skripsi. Fakultas Ekonomi Universitas Tanjungpura

Widiyanti. (2015). Pengaruh Financial Leverage Terhadap Profitabilitas Pada Perusahaan Sub Sektor Otomotif Dan Komponen Yang Terdaftar Di Bursa Efek Indonesia. Jurnal Manajemen dan Bisnis Sriwijaya Vol.13 No.1 Maret 2015.

Maulita. (2018). Pengaruh Debt To Equity Ratio (Der), Debt To Asset Ratio (Dar), Dan Long Term Debt To Equity Ratio (Lder) Terhadap Profitabilitas (Studi Pada Perusahaan Manufaktur Sub Sektor Makanan dan Minuman Yang Terdaftar Di BEI Periode 20112016). Jurnal Akuntansi, Vol 5 No. 2, Juli 2018.

Nugroho. (2011). Analisis pengaruh Likuiditas, Pertumbuhan Penjualan, Perputaran Modal Kerja, Ukuran Perusahaan dan Leverage terhadap profitabilitas perusahaan, Skripsi, Universitas Diponegoro, Semarang.

Putra. (2017). Pengaruh Corporate Governance Terhadap Profitabilitas Pada Perusahaan Perbankan yang Terdaftar di Bursa Efek Indonesia Periode 2013-2015). Jurnal Administrasi Bisnis (JAB)|Vol. 47 No.1 Juni 2017.

Utama. (2014). Pengaruh Current Ratio, Debt Equity Ratio, Debt Asset Ratio, Dan Perputaran Modal Kerja Terhadap Return On Asset Pada Perusahaan Manufaktur Yang Terdaftar Di Bursa Efek Indonesia Tahun 2010 - 2012. Diponegoro Journal Of Accounting Volume 03, Nomor 02, Tahun 2014

Veno. (2015). Pengaruh good corporate governance terhadap kinerja perusahaan pada perusahaan manufaktur go public. BENEFIT Jurnal Manajemen dan BisnisVolume 19, Nomor 1, Juni 2015, hlm 95-112.

Wikardi. (2017). Pengaruh Debt to Equity Ratio, Firm Size, Inventory Turnover, Assets Turnover dan Pertumbuhan Penjualan Terhadap Profitabilitas (Studi Kasus Pada Industri Makanan dan Minuman yang Terdaftar di BEI Periode 2011-2015). Jurnal Online Insan Akuntan, Vol.2, No.1, Juni 2017, 99 - 118.

Yulianawati. (2014) Pengaruh Good Corporate Governance dan Leverage Terhadap Kinerja Keuangan (Studi pada Perusahaan Manufaktur yang Terdaftar Di BEI Tahun 20112012. Skripsi. Surakarta : Fakultas Ekonomi dan Bisnis. Universitas Muhammdiyah Surakarta

Books, Chapters In Books, Reports, Etc.

One Author

33 | CAPITAL, VOLUME 3, NOMOR 1, SEPTEMBER 2019 
Fahmi, Irham. (2011). Analisis Kinerja Keuangan. Bandung: Alfabeta.

Fahmi, Irham. (2014. Analisis Kinerja Keuangan. ALFABETA CV BANDUNG.

Fahmi, Irham. (2015). Analisis Laporan Keuangan. ALFABETA CV BANDUNG.

Ghozali, I. (2006). Aplikasi Analisis Multivariate dengan SPSS (Cetakan Keempat ed.). Semarang: Badan Penerbit Universitas Diponegoro.

Ghozali, I. (2009. Aplikasi Analisis Multivariate dengan SPSS (Edisi Keempat ed.). Semarang: Badan Penerbit Universitas Diponegoro.

Hanafi. (2009). Analisis Laporan Keuangan. Yogyakarta: UPP STIM YKPN.

IAI. (2007). Standar Akuntansi Keuangan. Jakarta: Salemba Empat.

Kasmir. (2007). Bank dan Lembaga Keuangan Lainnya Edisi Enam. Jakarta: PT Gaja Grafindo Persada.

Sawir. (2008). Analisa Kinerja Keuangan dan Perencanaan Keuangan Perusahaan. Jakarta: PT Gramedia Pustaka Utama.

Subramanyam. (2010). Analisis Laporan Keuangan (Financial Statement Analysis). SALAMBA EMPAT.

Sartono, A. (2010). Manajemen Keuangan Teori dan Aplikasi.Edisi ke Empat. Yogyakarta. BPFE

Syamsuddin, L. (2011). Manajemen Keuangan Perusahaan: Konsep Aplikasi Dalam Perencanaan, Pengawasan dan Pengambilan Keputusan. EdisiBaru. Jakarta: Rajawali Press. 